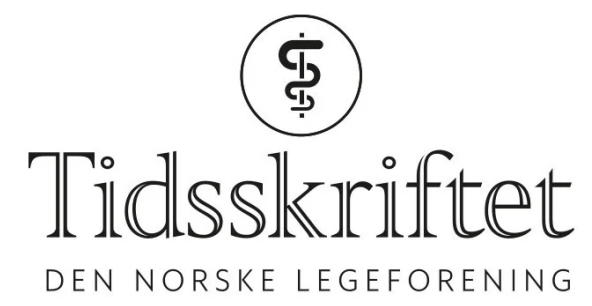

\title{
Hjertet og fornuften
}

INTERVJU

ANNE KATHRINE SEBJØRNSEN

Email: annekaths@hotmail.com

BUP Nordstrand

Barbro Lill Hætta var på stø kurs opp og frem, og ble stadig headhuntet til nye og spennende politiske posisjoner. Energien var uuttømmelig. Hun hadde erkjent at hun «satt med nøkkelsen til sitt eget liv i hånda» og at det bare var opp til henne selv å gripe sjansene. Så endret livet seg.

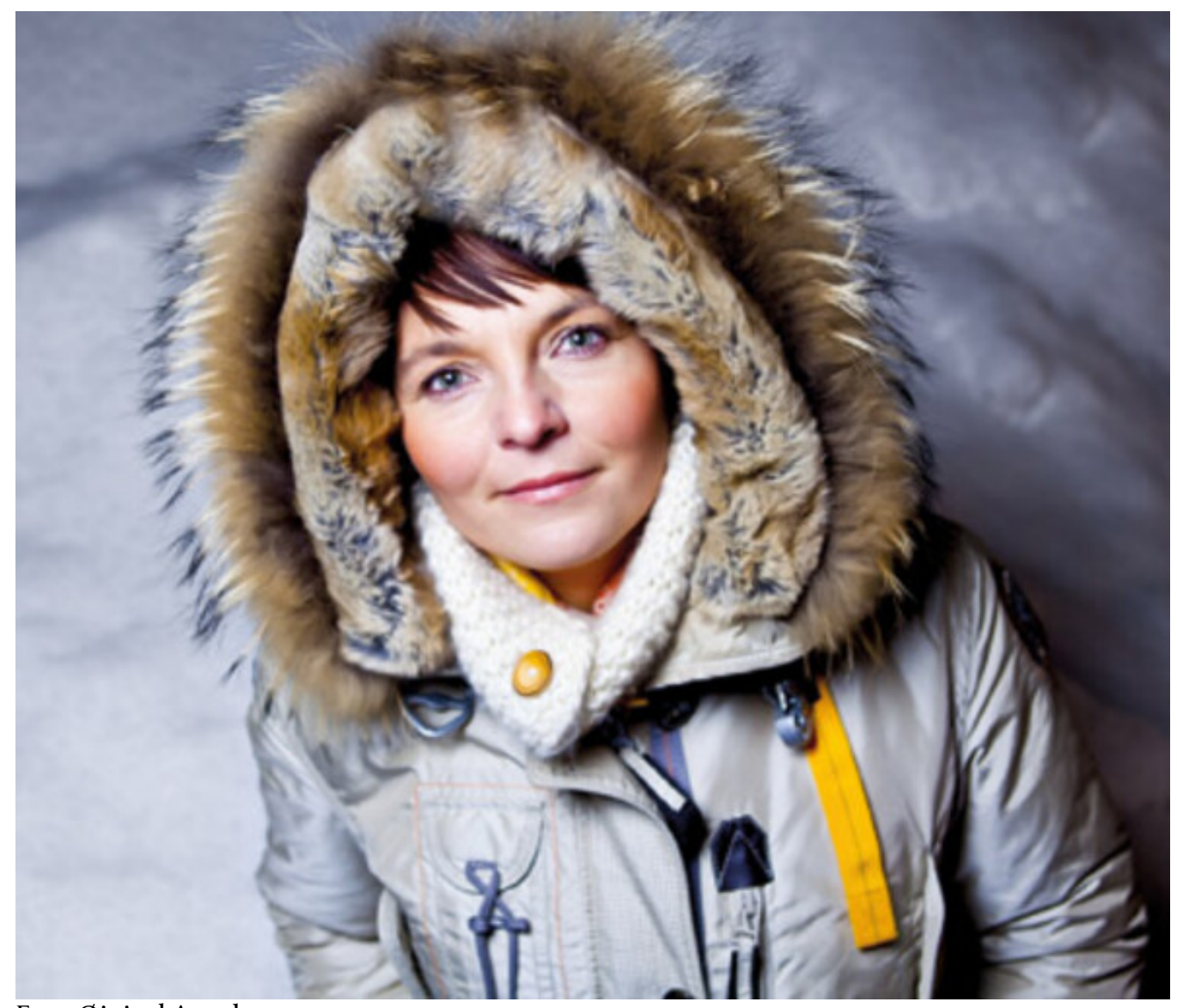

Foto Øivind Arvola 
Barbro Lill Hætta beveger seg med rolige, men målrettede skritt. Selvsikker, med en tilbakelent trygghet som også preger måten hun snakker på. Den ubestemmelige nordnorske dialekten avslører ikke hvor hun kommer fra, og det er først og fremst etternavnet som tilkjennegir det samiske opphavet. Noen års landflyktighet på Kolbotn i tidlige tenår bidro til at hun fikk identitet som norsk, men også at hun opplevde å bli avvist av sine egne da hun kom tilbake til Kautokeino.

- Jeg hadde mistet det samiske språket muntlig, og var plutselig blitt "den norske jenta» for de andre ungene. Det var absolutt ikke ment som en hedersbetegnelse, og jeg strevde lenge med å finne tilbake til den samiske identiteten. Jeg har også i voksen alder brukt mye tid på å ta tilbake det samiske språket i dagligtalen, slik at jeg kan ta det i bruk sammen med ungene mine, forteller hun.

Det var ikke opplagt at «den norske jenta» uten samisk talespråk skulle bli leder for Samisk språkråd få år senere. Men at hun skulle bli engasjert for å motivere samisk ungdom til å søke høyere utdanning var kanskje ikke like overraskende. Til tross for at ingen i hennes familie hadde noen akademisk bakgrunn, var hun ambisiøs og målrettet fra ung alder. Takket være en klar og tydelig mor.

- Jeg ville egentlig bli lærer, men min mor syntes det var en dårlig idé. Hun ga meg klar beskjed om å skaffe meg en utdanning som gjorde at jeg kunne forsørge familien min hvis jeg ble enslig, forteller hun med glimt i øyet.

- Oppfatter du deg mest samisk eller mest norsk i dag?

- Jeg er et produkt av den fornorskingen Kautokeino ble utsatt for i 1970-årene. Jeg har en tydelig samisk bakgrunn, men gikk i norsktalende klasse fordi foreldrene mine ikke ønsket at jeg skulle lære meg samisk. Det var ikke bra nok å være same den gangen, inntil blant annet Alta-aksjonen førte til en samisk oppvåkning. Jeg er veldig tokulturell og føler at det er nyttig fordi det gir meg et vidt perspektiv. Samtidig lever jeg midt i en kollisjon mellom norsk og samisk kultur.

- På hvilken måte?

- I Kautokeino er det status å ha mest rein, men det gir ikke nødvendigvis status å ha en doktorgrad. Det var ganske absurd å sitte i regjeringens privatfly hjem fra Genève og diskutere urfolkspolitikk med utenriksministeren på kvelden, for så å være en av ungdommene i Kautokeino neste dag, forteller Barbro Hætta.

- Har den samiske bakgrunnen vært nyttig i ditt virke som lege?

- Jeg opplever at jeg drar nytte av at jeg har med meg en bredde i min tilnærming til ulike mennesker. Mange av mine medstudenter hadde akademikerforeldre og var preget av det, mens jeg var opptatt av ikke å bedømme mennesker ut fra hvilken jobb de har. Sånn sett opplevde jeg en liten kulturkollisjon når det kom til holdninger. For øvrig fikk jeg skryt for mine ferdigheter i kirurgi tidlig i studiet, og kirurgen lurte på om jeg hadde operert før siden jeg hadde så godt håndlag med skalpellen. Det hadde jeg jo ikke, men jeg hadde vært sammen med en flyttsame i mange år og slaktet mange rein, flirer hun.

\section{Politikeren}

Barbro Hættas politiske liv opprant da hun som 12-åring engasjerte seg i å få reparert en tursti som var blitt tatt av vårflommen hjemme i Kautokeino. Som 16-åring meldte hun seg inn i Arbeiderpartiets lokallag, og en politisk spire, som senere skulle bli varaordfører i Harstad og politisk rådgiver i Jagland-regjeringen, begynte å gro. Hun ble i en alder av 24 år den første kvinnelige samepolitiske rådgiveren i Kommunaldepartementet.

- Jeg følte meg ung og utrygg i rollen, og etter en måned opplevde jeg at jeg gjorde en dårlig jobb. Jeg måtte på et tidspunkt bestemme meg for at jeg hadde noe å bidra med og tro på min egen kompetanse. Den prosessen var utrolig nyttig for å innse at det bare var jeg selv 
som kunne ta ansvar for livet mitt, og den erkjennelsen ble skjellsettende for meg som menneske.

- Hvordan klarte du å ta grep om situasjonen?

- Jeg bestemte meg for aktivt å ta lærdom av de erfaringene jeg gjorde underveis. Etter hvert eneste møte jeg var på, oppsummerte jeg hvordan møtet hadde forløpt, og var nøye med å gi meg selv ros, fremfor bare å devaluere egen innsats. Jeg identifiserte to ting som hadde gått bra, og én ting som kunne gjøres bedre. For øvrig klipte jeg håret og kjøpte meg klær som passet inn i departementet! Barbro Hætta smiler et smil som bekjenner at hun kan bruke kvinnelist når det trengs. De fleste kvinner vet at det hjelper å føle seg korrekt antrukket i situasjonen.

- På hvilken måte har du dratt nytte av erfaringene du gjorde deg i denne situasjonen?

- Det var nyttig for meg å ha kjent på at en oppgave ble for stor for meg. Jeg er et overskuddsmenneske, men jeg skulle komme til å oppleve at også jeg hadde begrensninger da familiesituasjonen senere skulle vise seg å bli annerledes enn vi hadde «bestilt», forteller hun.

Fire måneder før hun skulle avlegge medisinsk embetseksamen ble hun forespurt av daværende helseminister Tore Tønne om å bli politisk rådgiver i Helsedepartementet, men takket nei da hun innså at veien tilbake til en klinisk hverdag ville bli for tung å gå. Fire dager før sensuren falt, ringte han igjen for å høre om hun hadde ombestemt seg.

- Det var et utrolig fristende tilbud, og jeg brukte lang tid på å bestemme meg. Det var virkelig en kamp mellom hjertet og fornuften, men jeg visste at jeg ikke ville klare å komme tilbake til medisinen hvis jeg satset fullt på politikken uten å ha arbeidet som lege. Jeg ønsket ikke å være en politisk broiler. Nå føler jeg at det var et veldig godt valg, og at legeyrket er veldig riktig for meg. Jeg var i praksis ferdig spesialist i allmennmedisin og stortrivdes i faget da jeg sluttet og begynte i barne- og ungdomspsykiatrien for et par år siden.

- Hva var det som som gjorde at du endret fagretning?

- Vi fikk et barn som var mye våken hver natt, og det ble etter hvert oppdaget at han har $\mathrm{AD} / \mathrm{HD}$ og autistiske trekk, samt en moderat psykisk utviklingshemning i tillegg til en rekke somatiske lidelser. Den høsten han nesten ikke sov, ble det tydelig for meg at jeg måtte gjøre noen prioriteringer. Jeg var på den tiden fastlege i egen privat praksis,varaordfører i Harstad, og hadde i tillegg en rekke styreverv. Det endte med at jeg enkelte dager måtte sove en halv time på undersøkelsesbenken på kontoret for å komme meg gjennom dagen.

- Det var en ny opplevelse for deg å ha begrensninger?

- Livet setter til enhver tid noen premisser. Jeg var vant til å planlegge og få det som jeg ville, men dette var noe jeg ikke styrte over. Jeg brukte tid på å venne meg til at at livet var i ferd med å ta en annen retning enn jeg hadde tenkt, og det tok meg tid å finne meg til rette i den nye situasjonen. Vi måtte rett og slett endre den bestillingen vi hadde lagt inn på et friskt og velfungerende barn. Slik jeg føler det, handler det ikke om en forsakelse, for jeg ser på ham som et fullkomment menneske som beriker mitt liv. Han gir et mangfold, i likhet med det mangfoldige politiske engasjementet jeg har. Han er annerledes, men fullkommen, og han gir så mye mer enn han krever.

- Du solgte fastlegepraksisen?

- Ja, jeg opplevde at det var strevsomme dager i allmennpraksis når hjemmesituasjonen ble som den ble. Det gikk utover kollegene når jeg var borte, og jeg måtte uansett ta igjen det forsømte når jeg kom tilbake igjen. Jeg er en allmennpraktikertype og stortrivdes i rollen som fastlege, men det ble etter hvert klart for meg at jeg måtte velge mellom det og de 
andre engasjementene mine. Jeg utsatte stadig å selge praksisen, for jeg fikk et veldig spesielt forhold til mange av familiene, og mangfoldet $i$ allmennpraksis var utrolig givende for meg.

- Hvordan ser livet ut nå?

- Det har vært noen krevende år, men endelig er ting i ferd med å falle på plass. Jeg stortrives i barne- og ungdomspsykiatrien, og opplever at det er et utrolig godt tverrfaglig samarbeid med den målsetting å gi pasientene en best mulig hverdag. Når det gjelder familiesituasjonen, så har det vært mange års kamp for å utløse de rettighetene sønnen vår har krav på, men nå ser ting ut til å løse seg. Jeg har de siste årene lært at jeg ikke kan få alle svarene på én gang. Tiden gir en del svar, og åpner noen dører.

\section{Styregrossisten}

- Du har styreverv i en rekke ulike bedrifter som favner en mengde fagområder, deriblant sitter du i styret til Oslo universitetssykehus, i bedriftsforsamlingen til Statoil, i styret til Festspillene i Nord-Norge, og du satt i styret til Tromsø 2018. For ikke å glemme at du var kandidat til vervet som visepresident i Norges Idrettsforbund?! Mangfold er et stikkord som kjennetegner både din kulturelle bakgrunn og dine mange engasjementer?

- Jeg har et overordnet ønske om å bidra til et bedre samfunn. I politikken kan jeg ha innflytelse på samfunnsutviklingen, og det føler jeg også at jeg kan som lege. Det er naturlig for meg å ta utgangspunkt i fagfelter jeg kjenner, men etter hvert har jeg blitt ganske allsidig, og har engasjert meg i alt fra boligpolitikk til olje og kultur. Jeg har ikke noen higen etter karriere, men prøver å leve livet så optimalt som mulig i dets ulike faser. Jeg har innsett at jeg ikke kan gjøre alt samtidig, og at ulike ting er viktige i forskjellige perioder av livet. Men politikken beriker livet mitt, og jeg får brukt meg selv som mer enn lege og mor.

- Hva gjør du for å hente krefter?

- Med jevne mellomrom må jeg dra på fjellet i noen dager, og jeg må være der alene. Det tok lang tid for mannen min å forstå at jeg måtte være alene på vidda for å finne roen, men sånn er det bare.

- Men du har trappet ned det politiske engasjementet ditt betraktelig de seneste årene?

- Livet byr på så mange muligheter, og jeg har innsett at jeg ikke kan gjøre alt samtidig. Mannen min har 8 o reisedøgn i året som legemiddelkonsulent, og med to små barn var det nødvendig å gjøre noen omprioriteringer. Akkurat nå krever rollen som mor mer av tiden min, og jeg har begrenset meg til enkelte styreverv og et visst lokalpolitisk engasjement. Jeg kunne ha fortsatt som fastlege hvis jeg hadde kuttet ned på andre ting, men jeg måtte gjøre et valg.

- Alt til sin tid?

- Jeg sammenlikner det med å male et bilde. Først fyller du det ut med de tingene som må være til stede i bildet, deretter kan du fylle inn med detaljer. Jeg er opptatt av at alle elementene i bildet skal være givende, men ikke tappende.

\section{Tabell}


Barbro Lill Hætta

Født 23. april 1972

- Lege i spesialisering BUP Sør-Troms, Universitetssykehuset Nord-Norge, Harstad, 2008-

- Fastlege i Harstad kommune, 2002-08

- Cand.med. Universitetet i Tromsø, 2000

- Varaordfører i Harstad kommune, desember 2005-09

- Kommunestyrerepresentant og sitter i formannskapet for Arbeiderpartiet i Harstad kommune, desember 2005-

Publisert: 21. januar 2011. Tidsskr Nor Legeforen. DOI: 10.4045/tidsskr.10.1411

(C) Tidsskrift for Den norske legeforening 2023. Lastet ned fra tidsskriftet.no 26. april 2023. 